\title{
COERCIVE INVESTIGATION OF CORPORATE CRIME: WHAT INVESTIGATORS SAY
}

\author{
EUGENE SCHOFIELD-GEORGESON*
}

\begin{abstract}
This study investigates the use of coercive investigation powers in the context of corporate crime, based on a series of interviews with former Australian Securities and Investments Commission ('ASIC') enforcement officials and corporate lawyers. It argues that ASIC's powers are well equipped to investigate corporate crime, but that ASIC rarely exercises these powers. In this respect, the article draws similar conclusions to the recent Royal Commission into Misconduct in the Banking, Superannuation and Financial Services Industry, but delves further, revealing how coercive powers are used and why they are seldom exercised in corporate criminal investigations. In accounting for this institutional failure, this study implicates a neoliberal agenda of deregulation and austerity that has permitted the regulator to be 'captured' by wealthy and powerful regulatees. The analysis is informed by a critical regulation approach to corporate crime that explains corporate or 'white-collar' crime and its enforcement through a sociological lens: as a result of unequal social relationships, primarily that of social class, that create disparities in legal and political power.
\end{abstract}

\section{INTRODUCTION}

In the post-war period, liberal democracies have vested officials from regulatory agencies with 'special' or coercive investigative powers. These powers bypass traditional civil liberties such as the right to silence and privilege against self-incrimination. ${ }^{1}$ This has largely occurred in a law enforcement context that is mostly defined by wealthy and powerful interests or 'regulatees' - individual and

* The author, Dr Eugene Schofield-Georgeson, is a lecturer at the University of Technology (UTS) Faculty of Law. The author extends his thanks and gratitude to each interview participant in this study for sharing their valuable insights and experience - without which this article would not have been possible.

1 Administrative Review Council, The Coercive Information-Gathering Powers of Government Agencies (Report No 48, 1 May 2008) 5, 71-93 ('ARC'); Australian Law Reform Commission, Traditional Rights and Freedoms: Encroachments by Commonwealth Laws (Report No 129, 23 December 2015) 309-11. The right of silence is a separate and distinct immunity to the privilege against self-incrimination and each have different historical origins: $R v$ Director of Serious Fraud Office; Ex parte Smith [1993] AC 1, 30-1 (Lord Mustill) cited in Environment Protection Authority v Caltex Refining Co Pty Ltd (1993) 178 CLR 477, 503 (Mason CJ and Toohey J). 
corporate - endowed to resist law and regulation. Precisely how 'extraordinary' powers are used in this context, and to what effect, has scarcely been the subject of scholarly research. Despite a large-scale and recent Australian Royal Commission into Misconduct in the Banking, Superannuation and Financial Services Industry ('the Banking Royal Commission') recommending more whitecollar prosecutions, ${ }^{2}$ the role that coercive powers play in the prosecution process remains largely unexplored.

This article examines the use of coercive powers in the investigation of corporate crime by the Australian Securities and Investments Commission ('ASIC'), a regulatory agency, through analysis of interviews with former ASIC enforcement officials and corporate lawyers. It argues that ASIC's powers are well equipped to investigate corporate crime but that ASIC rarely exercises these powers. This article first examines why ASIC's powers are well 'assimilated', meaning that they enable the regulator to target and police white-collar crime as effectively as regular police powers (Part A 'Assimilation and Efficacy of ASIC's Special Powers to Investigate Corporate Crime'). Second, this article reveals how coercive powers are 'differentiated', or rather, why ASIC investigators rarely use their powers to prosecute corporate crime, as police do against regular crime (Part B 'Differentiation and Under-Enforcement of Corporate Crime Relating to ASIC's Special Powers'). ${ }^{3}$ In this respect, the article delves further than the findings of the Banking Royal Commission, engaging with the institutional causes of enforcement failure. The most significant implicate a neoliberal agenda of deregulation and austerity, affecting funding, staffing, skills and formal enforcement policy within the regulator, thereby facilitating white-collar crime by permitting the regulator's 'capture' by wealthy and powerful regulatees. The analysis is informed by a critical regulation approach ${ }^{4}$ to corporate crime that explains corporate or 'whitecollar' crime and its enforcement through a sociological lens: as a result of unequal social relationships, primarily that of social class, that create disparities in legal and political power.

ASIC's coercive powers of investigation are not without controversy ${ }^{5}$ and the necessity of these powers, compared to regular police powers, is discussed at

2 Royal Commission into Misconduct in the Banking, Superannuation and Financial Services Industry (Final Report, 1 February 2019) vol 1446 Recommendation 6.2 ('Banking Royal Commission').

3 Where indictable offences are concerned, the Commonwealth Director of Public Prosecutions ('DPP'), not ASIC, is required to make the final decision to prosecute an offence in court (state and territory DPPs are required to do the same): Australian Securities and Investment Commission and Commonwealth Director of Public Prosecutions, 'Memorandum of Understanding' (1 March 2006) [4.1]-[4.3] cited in Australian Securities and Investments Commission v Rich [2004] NSWSC 1089, [53]. Nevertheless, ASIC investigators must make a decision to initiate the prosecution process through the gathering of evidence to prove an offence (in a similar manner to state and territory police forces).

4 Steve Tombs and Dave Whyte, Safety Crimes (Willan Publishing, 2007); Harry Glasbeek, Capitalism: A Crime Story (Between the Lines, 2018); Frank Pearce and Steve Tombs, Toxic Capitalism: Corporate Crime and the Chemical Industry (Dartmouth Publishing, 1998). It draws on the theoretical explanation of corporate crime, pioneered by North American sociologist, Ed Sutherland, in the 1940s: see below Part II.

5 Strong arguments against these powers have, for instance, been voiced in Jeremy Gans, Submission No 77 to Australian Law Reform Commission, Freedoms Inquiry (2015), as well as in the dissenting views of Senators Barney Cooney, Ian Campbell and Frank Ford MP in Joint Statutory Committee on 
length in Part A(4) of this article through the concept of 'assimilation'. Before analysing this concept in detail, however, the necessity of these powers warrants brief explanation. Corporate crime is unlike conventional crime in a range of ways. It often involves complex facts and is difficult to detect, requiring wide powers to demand production of documentary evidence essential to its prosecution. Unlike other crime, the immediate victim of corporate offending is often indeterminate: society at large, a broad group of customers or investors, or the corporation itself. In this respect, the corporation is an inanimate legal fiction often controlled by the perpetrator. Unlike human victims and witnesses to a crime of theft, within corporations, witnesses to complex fraud are frequently non-existent, necessitating respective powers to compel oral evidence from suspects. ${ }^{6}$ Without such powers, ASIC could not achieve its regulatory objectives of ensuring confidence in the integrity of Australian financial markets while enforcing compliance with regulatory law while deterring its breach. ${ }^{7}$ Failing to enforce the law in this context results in a general perception of bias or unfairness as to the class-based nature of law enforcement - a perception of lawlessness that undermines the market itself. According to current economic orthodoxy, loss of investor and creditor confidence in market regulation, for instance, might result in a shift of global capital to other jurisdictions that uphold the rule of law. ${ }^{8}$ The Federal Court of Australia has recognised that such capital outflows could detrimentally affect the economic welfare of all Australians. ${ }^{9}$

\section{THE LITERATURE}

The use of coercive investigation powers against white-collar crime is a topic that requires explanation by reference to an interdisciplinary literature, drawing upon scholarship in the fields of corporate, criminal and evidence law, as well as regulation theory and criminology. Absent from much of this literature is a critical and detailed analysis of structural and institutional relationships involving social power. Power, of course, is implicit within law enforcement against 'the crimes of the powerful'. ${ }^{10}$ As critical regulation scholars such as Frank Pearce, Harry Glasbeek, Steve Tombs and Dave Whyte make clear, class power is at the centre of corporate or white-collar crime and is the reason for its 'regulation', rather than

Corporations and Securities, Parliament of Australia, Use Immunity Provisions in the Corporations Law and the Australian Securities Commission Law (1991), 31.

6 Joint Statutory Committee on Corporations and Securities, Parliament of Australia, Use Immunity Provisions in the Corporations Law and the Australian Securities Commission Law (Final Report, 13 November 1991) 26 [4.8] ('Use Immunity Report').

7 Australian Securities and Investments Commission Act 2001 (Cth) s 1(2) ('ASIC Act').

8 Bogdan Dima, Flavia Barna and Miruna-Lucia Nachescu, 'Does Rule of Law Support the Capital Market?' (2018) 31(1) Economic Research 461, 476; Laura Alfaro, Sebnem Kalemli-Ozcan and Vadym Volosovych, 'Capital Flows in a Globalized World: The Role of Policies and Institutions' (Working Paper No 11696, Conference on Capital Controls and Capital Flows in Emerging Economies: Policies, Practices and Consequences, National Bureau of Economic Research, October 2005).

9 Australian Securities and Investment Commission v Whitebox Trading Pty Ltd [No 7] [2019] FCA 849, [16]-[19] (Yates J).

10 Frank Pearce, The Crimes of the Powerful: Marxism, Crime and Deviance (Pluto Press, 1976). 
its policing..$^{11}$ According to these scholars, the resurgence of ruling-class power in the neoliberal era has been associated with more recent 'deregulated' enforcement policies of 'compliance' and 'self-regulation', as opposed to criminalisation, deterrence and prosecution. ${ }^{12}$

Foremost among accounts of corporate or 'white-collar' crime is the work of Edwin Sutherland in the 1940s. ${ }^{13}$ Building on the work of French political economists Rusche and Kirchheimer in the 1930s, ${ }^{14}$ Sutherland developed a theory of corporate crime in which he understood the class-biased development and implementation as leading to corporate crime being treated differently to other kinds of crime, such as 'blue-collar' or 'street' crime. ${ }^{15} \mathrm{He}$ called such crime 'white collar crime', which he defined as 'a crime committed by a person of respectability and high social status in the course of his [sic] occupation'. ${ }^{16}$ Crucially, Sutherland's definition extended beyond 'individual characteristics' pertaining to white-collar offenders (status, career, income, etc), ${ }^{17}$ straddling the social relations of corporate offending. 'Powerful business and professional men', wrote Sutherland, routinely commit crimes but escape detection and prosecution because of the class bias of courts and 'the power of their class to influence the implementation and administration of the law'.18

As important to Sutherland's theory was his idea of a continuum in the administration and punishment of crime. At one end of the continuum are types of crime treated by the law as mala in se or inherently wrong - crimes against the person, drug offences and property offences ('street crime') - corresponding with methods of enforcement, for instance by police, that treat such offences as inherently bad. At the other end of the continuum are types of crime that Sutherland labelled, mala prohibita, meaning wrong because they are prohibited by law. These offences usually include corporate crime and other 'regulatory offences', most often 'differentiated' from street crime through their legal definition as 'civil', or 'technical violations [of law] ... [involving] no moral culpability'. ${ }^{19}$ Enforcement of these offences is usually conducted by regulatory agencies.

Since the time of Sutherland, this theory has had important implications for law-makers and legal theorists. First, it has meant that definitions of corporate

11 Glasbeek (n 4); Pearce and Tombs (n 4); Tombs and Whyte (n 4).

12 Glasbeek (n 4); Pearce and Tombs (n 4); Tombs and Whyte (n 4).

13 Edwin Sutherland, 'White-Collar Criminality' (1940) 5(1) American Sociological Review 1; Edwin H Sutherland, White Collar Crime (Holt Reinhart and Winston, 1949).

14 Georg Rusche and Otto Kirchheimer, Punishment and Social Structure (Columbia University Press, 1939).

15 Sutherland, 'White-Collar Criminality' (n 13) 8.

16 Edwin Sutherland, White Collar Crime: The Uncut Version (Yale University Press, 1983) 7.

17 An 'individual characteristics' or Durkheimian approach to sociological understandings of the concept of social class - such as that adopted by Pierre Bourdieu (1976) and Guy Standing (2011) - is eschewed by Erik Olin Wright and others, who caution that it fails to account for social relations between classes (Weber), as well as their exploitative and oppressive consequences (Marx): Erik Olin Wright,

Understanding Class (Verso, 2015) 3-13. In other words, such approaches avoid the issue of power.

18 Sutherland, 'White-Collar Criminality' (n 13) 7,9.

19 Edwin H Sutherland, 'Is "White Collar Crime" Crime?' (1945) 10(2) American Sociological Review 132, 139; Tombs and Whyte (n 4) 94-5. 
crime must be expansive, such as that suggested by sociologists Frank Pearce and Steve Tombs, which includes ${ }^{20}$

[i]llegal acts or omissions, punishable by the state under administrative, civil or criminal law, which are the result of deliberate decision making or culpable negligence within a legitimate formal organisation. These acts of omissions are based in legitimate, formal, business organisations, made in accordance with the normative goals, standard operating procedures, and/or cultural norms of the organisation, and are intended to benefit the corporation itself. ${ }^{21}$

It is this definition of corporate crime that is deployed here. In the present context, the type of corporate crime investigated by ASIC predominantly involves contraventions of the Corporations Act 2001 (Cth) ('Corporations Act') in conjunction with the Criminal Code Act 1995 (Cth). The residual provisions of the Criminal Code (sections 3-5) prescribe 'fault elements' (negligence, recklessness, knowledge or intention) and 'physical elements' (acts or omissions) for all Commonwealth offences. These provisions apply to all offences outlined in the Corporations Act, unless expressly overridden by a legislative statement to the contrary (eg, that an offence is one of 'strict liability'; or involves a fault element of 'intentional dishonesty or recklessness' (Corporations Act section 184)). ${ }^{22}$

A second implication arising from Sutherland's observation is that white-collar crime is differentiated from street crime by law and procedure. In translating this observation into meaningful law reform (and thereby bridging an 'is-ought' distinction in Sutherland's theory), ${ }^{23}$ critical regulation scholars - predominantly in the field of corporate work health and safety crime ${ }^{24}$ - have suggested that progress in the field of corporate crime requires the assimilation of currently differentiated mala prohibita patterns of regulatory law and enforcement toward the mala in se model. Sutherland's continuum of 'assimilated' and 'differentiated' criminal offending is the key theoretical lens through which the interview responses in this study are examined - categorised respectively within Part A(1) ('Assimilation of Investigation Powers') and Part B(1) ('Differentiation of Investigation Powers') of this article.

It is noted that the rise in small business and the lowering of class barriers in certain professions since the $1970 \mathrm{~s}^{25}$ might be seen to challenge the contemporary relevance of Sutherland's theory regarding corporate and professional power,

20 Pearce and Tombs (n 4) 107-10.

21 Similar definitions are also provided by Ronald C Kramer, 'Corporate Criminality: The Development of an Idea' in Ellen Hochstedler (ed), Corporations as Criminals (Sage, 1984) 13-37; Steven Box, Power, Crime and Mystification (Tavistock Publications, 1983) 19-23.

22 Gore v Australian Securities and Investments Commission (2017) 249 FCR 167, 170-1 [3] (Dowsett and Gleeson JJ); DPP (Cth) v Poniatowska (2011) 244 CLR 408, 416-17 [20], 417-19 [24]-[25] (French CJ, Gummow, Kiefel and Bell JJ).

23 Sometimes referred to as 'Hume's Guillotine'.

24 Tombs and Whyte (n 4) 125-43; Glasbeek (n 4).

25 Michael Schaper, 'A Brief History of Small Business in Australia, 1970-2010' (2014) 3(2) Journal of Entrepreneurship and Public Policy 222, 223. See also Margaret Thornton, who discusses this process specifically in relation to the 'declining status of lawyers', precipitated by 'deprofessionalisation, coupled with greater scrutiny and accountability' as well as 'the 'massification' of higher education and information technology', in 'The Australian Legal Profession: Toward a National Identity' in William LF Felstiner (ed), Reorganisation and Resistance: Legal Professions Confront a Changing World (Hart Publishing, 2005) 133, 135. 
particularly where small business has entered the arena of corporate regulation. This social change is reflected in ASIC enforcement statistics between 2016 and 2019 , indicating that coercive powers are conventionally exercised against smaller and less powerful businesses, while large and more powerful corporations mostly escape prosecution (discussed further in Part $\mathrm{B}(1)$ below). ${ }^{26}$ It must be remembered, however, that changing work patterns since the 1970s coincided with largescale labour market deregulation, casualisation and a growth in unemployment, driving some workers to seek subsistence work - work characterised by a legal designation as 'small business' ${ }^{27}$ When the enforcement statistics are read in this context, it is difficult to dispute the contemporary relevance of Sutherland's work and that of other critical regulation scholars: that the crimes of the powerful continue to evade law enforcement (often at the expense of a social majority).

Sutherland's view that corporate crime must be treated as crime and taken more seriously by law-makers and enforcement officials, is echoed by modern regulatory theory, reverberating in the findings of Justice Kenneth Hayne in the Banking Royal Commission. As Hayne found, ASIC should place greater emphasis on 'deterrence' and 'prosecution' of corporate crime. ${ }^{28}$ This view builds upon the theoretical regulatory strategy known as 'enforcement-backed compliance', ${ }^{29}$ as well as basic paradigms of 'responsive regulation theory', ${ }^{30}$ and the lesser known, 'really responsive regulation theory' ${ }^{31}$ Problematically, however, these regulatory approaches lack a key element that Sutherland's approach makes explicit: that at the heart of corporate wrongdoing are intractable forms of class power and privilege enabling white-collar criminals to not only evade the law, but to affect and prevent lawmaking and its enforcement.

In this study, class power appeared to lie at the root of neoliberal policies associated with 'regulatory capture' and the persistent differentiation of corporate crime by senior management within the regulator, ASIC. As was apparent, the coercive legal power required to assimilate white-collar crime to conventional models of criminal law enforcement already exists. But as interviewees explained, the pervasive influence of neoliberal management policy, together with similarly politicised market regulation ('compliance'-oriented regulation) from the topdown within ASIC, has severely curtailed coercive enforcement practices.

26 Australian Securities and Investment Commission, 'Enforcement Outcomes', Periodic Reports (Web Page) $<$ https://asic.gov.au/about-asic/asic-investigations-and-enforcement/asic-enforcement-outcomes/> ('Enforcement Outcomes').

27 Stephen Castles and Jock Collins, 'Restructuring, Migrant Labour Markets and Small Business', (Occasional Paper No 16, Centre for Multicultural Studies, University of Wollongong, June 1989) 13; Tomas Marttila, The Culture of Enterprise in Neoliberalism: Spectres of Entrepreneurship (Routledge, 2013) 100-11.

28 Banking Royal Commission (n 2) 424-46.

29 Neil Gunningham, 'Compliance, Deterrence and Beyond' in LeRoy C Paddock, David L Markell and Nicholas S Bryner (eds), Compliance and Enforcement of Environmental Law (Edward Elgar Publishing, 2017) 63, 66; Tombs and Whyte (n 4) 153-7. The work of Ian Ayres and John Braithwaite, Responsive Regulation: Transcending the Deregulation Debate (Oxford University Press, 1992) was foundational to the development of this practice.

$30 \quad$ Ayres and Braithwaite (n 29) 19-53.

31 Robert Baldwin and Julia Black, 'Really Responsive Regulation' (2008) 71(1) Modern Law Review 59. 
Compounding this was the observation that institutional knowledge about effective use of coercive powers is rapidly fading.

\section{THE LEGAL FRAMEWORK}

There are two key coercive powers available to ASIC to investigate corporate crime. ASIC may compel a person to either: (i) attend examinations and answer questions under oath ('examination powers'); ${ }^{32}$ and/or (ii) produce specified documents ('production powers'). ${ }^{33}$ Failure of a person to attend an examination and answer questions or produce a document is punishable by a fine or two years imprisonment. ${ }^{34}$ During an examination, a person may assert their privilege against self-incrimination (usually by saying the word 'privilege') before any answer that may incriminate them. Privileged interview answers cannot be used to prosecute a person in civil penalty or criminal proceedings. ${ }^{35}$ Such evidence may only be used to prosecute a person for giving false evidence. ${ }^{36}$ This loophole creates an immunity from prosecution that preserves the privilege against self-incrimination to a limited extent. It is known as 'direct use immunity' ${ }^{37}$ Nevertheless, it does not prevent 'derivative use' of the evidence - using the evidence to gain 'leads' to gather further evidence that may be crucial to a conviction. ${ }^{38}$ Nor does direct use immunity prevent investigators from using privileged evidence in court for another purpose such as to impugn a witness or defendant's credibility, to show that the statement was a lie or to establish consciousness of guilt. ${ }^{39}$ Neither the privilege against self-incrimination, nor derivative and direct use immunities apply to a corporation as they have been held only to apply to a natural person who possesses

32 ASIC Act 2001 (Cth) s 19. This section was often used as a verb by interviewees, eg, 'we section nineteened him'.

33 Ibid ss $30,33$.

34 Ibid s 63

35 Ibid ss 68(2)-(3).

36 Ibid.

37 See, eg, $A-G$ (Vic) v Riach [1978] VR 301, 310-11 (Kaye J) ('Riach'); Smith v The Queen (2007) 35 WAR 201, 226 [75] (Buss JA) ('Smith'); Paul Sofronoff, 'Derivative Use Immunity and the Investigation of Corporate Wrongdoing' (1994) 10 Queensland University of Technology Law Journal 122, 125.

38 In Riach, at 311, Justice Kaye contemplated the lawfulness of the derivative use of compelled evidence (investigative leads), saying that ' $[\mathrm{w}]$ hat might be discovered from investigations made as a result of a witness's statement in the course of evidence, would not be a link in a chain of evidence'. In the same passage, however, his Honour excluded any direct use of that evidence to prosecute a witness, saying '... evidence given by the witness, which might provoke investigation, would be inadmissible in any prosecution against him'. This situation was codified by section 68(1) of the ASIC Act 2001 (Cth) - the purpose of which is to compel evidence from witnesses, in order to provide investigators with leads or derivative evidence while (under section 68(3)) prohibiting direct use of such evidence. In the process of codification, two exceptions to direct use immunity were added under ss 68(3)(c) and (d). These subsections permit the use of compelled evidence to show 'the falsity of the statement' or 'the falsity of any statement contained in the record'. That is, compelled evidence (such as that created during an ASIC 's 19 examination' interview transcript) may be used against a person in court in criminal proceedings for these discrete and specific purposes, as recognised by Buss JA in Smith (at [75]). It is in this way that counsel use such false statements to impugn credibility etc. 
'human' rights. ${ }^{40}$ And neither may natural persons claim an evidential immunity in response to an ASIC request to produce documents or books. ${ }^{41}$ Indeed, there are few limitations on these powers, with the High Court treading lightly to ensure only that compulsory interviews are held before charges are laid, thereby merely reducing the possibility of forced confession. ${ }^{42}$

Similar powers limiting silence rights now belong to a host of other Australian regulatory agencies such as the Australian Prudential Regulation Authority ('APRA'), the Department of Human Services (which includes Medicare and Centrelink), the Australian Tax Office ('ATO') and the Australian Competition and Consumer Commission ('ACCC'). ${ }^{43}$ In reviewing these powers, some have suggested that they have the potential to infringe universal human rights and individual civil liberties. ${ }^{44}$ Other commentators propose that such powers should be uniform across a range of regulatory agencies ${ }^{45}$ Missing from both regulatory perspectives, however, is an understanding of power. ${ }^{46}$ Specifically, these perspectives fail to grasp how class power operates within corporate crime to thwart law enforcement, thereby necessitating stronger powers of investigation for specifically corporate regulatory agencies. Informed by a theoretical perspective that properly understands white-collar crime, agencies that regulate capitalism (such as those identified by corporate law scholar Thomas Middleton $)^{47}$ should be equipped with different and stronger powers of investigation and enforcement. The social relations of corporate crime mean that coercive power is, to invoke Sutherland's continuum or spectrum, well-assimilated to enforcing corporate criminal law. This article is not the appropriate forum to discuss investigation and enforcement powers of other, predominantly social welfare regulatory agencies, such as Medicare and Centrelink. However, a comparative approach to investigative powers between agencies based on understandings of social power is worthy of further study.

40 Environment Protection Authority v Caltex Refining Co Pty Ltd (1993) 178 CLR 477, 507-8 (Mason CJ and Toohey J). This common law authority is echoed by the Corporations Act, section 1316A, prohibiting corporations from claiming both the privilege against self-incrimination and the penalty privilege in criminal proceedings under the Act. Neither can a corporation be issued a section 19 examination notice, although it can be issued a notice to produce books: Smorgon v Australia and New Zealand Banking Group Ltd (1976) 134 CLR 475, 481-5 (Stephen J).

41 ASIC Act 2001 (Cth) s 68(1).

$42 \quad X 7 v$ Australian Crime Commission (2013) 248 CLR 92, 110-11 [25]-[27] (French CJ and Crennan J) (' $X 7^{\prime}$ ').

$43 \quad A R C$ (n 1) 72-94.

44 Ibid 2, 20-1; Joseph P Longo, 'The Powers of Investigation of the Australian Securities Commission: Balancing the Interests of Persons and Companies under Investigation with the Interests of the State' (1992) 10(4) Company and Securities Law Journal 237, 251; John Cotton, 'Australia: Self-Incrimination in Company Legislation' (1998) 19(6) Company Lawyer 182, 184.

45 Thomas Middleton, 'The Privilege Against Self-Incrimination, the Penalty Privilege and Legal Professional Privilege under the Laws Governing ASIC, APRA, the ACCC and the ATO: Suggested Reforms' (2008) 30 Australian Bar Review 282, 285.

46 To be fair, Middleton's suggestions for uniformity are limited to Commonwealth agencies that regulate capitalism.

47 Middleton ( $\mathrm{n} 45)$. 


\section{METHODS}

This study deployed qualitative research methods, relying on 14 semistructured interviews. ${ }^{48}$ Participants included former ASIC enforcement staff, investigators and corporate lawyers. Around half had held senior positions within the organisation and most had worked at ASIC over the past decade for between two and 25 years. Interviews were conducted by the researcher over a period of four months between late 2018 and early 2019, mostly at the workplaces of participants in Sydney, Adelaide, Melbourne and Brisbane. Each interview was roughly one hour in duration.

Semi-structured interviews were an appropriate research method for this study because they allowed participants space to explore the interpretive and theoretical nature of enforcement practices ${ }^{49}$ Data from interviews was sorted into fragments, organised around a thematic analysis of the assimilation and differentiation of white-collar crime..$^{50}$ Qualitative claims by participants were checked against existing quantitative data on ASIC enforcement operations. ${ }^{51}$ Similar interview methods to those used here have, in fact, been used previously in relation to ASIC enforcement officials, albeit with a larger focus on enforcement patterns ${ }^{52}$ and penalties, ${ }^{53}$ rather than investigative powers. As qualitative methods expert David Silverman argues, interviews provide the researcher with a study of 'experience', often neglected by large, official inquiries and quantitative or numerical data. ${ }^{54}$

\section{A Assimilation and Efficacy of ASIC's Special Powers to Investigate Corporate Crime}

\section{Assimilation of Investigation Powers}

Part A of this study examines how ASIC's special powers are used, assessing whether they are effective to investigate corporate crime. This assessment is informed by an appraisal of how well 'assimilated' these powers are in treating white-collar offending as mala in se crime. The assimilation of these powers was pivotal to interviewee discussion of their experience using coercive powers and most prefaced their comments by providing a perspective on corporate crime, triggering further discussion on the fairness of the powers to suspects. Interviewees were also asked to appraise the strength and efficacy of the powers, as well as how

48 Approved by the University of Technology Sydney Human Research Ethics Committee (ETH18-2582).

49 Social science research methods expert, Alan Bryman, recommends semi-structured interviews in precisely these projects: Alan Bryman, Social Research Methods (Oxford University Press, $4^{\text {th }}$ ed, 2012) 208-12.

$50 \quad$ Ibid 577-82.

51 Ian Ramsay and Miranda Webster, 'ASIC Enforcement Outcomes: Trends and Analysis' (2017) 35(5) Company and Securities Law Journal 289; Australian Securities and Investments Commission, 'Enforcement Outcomes' (n 26).

52 Helen Bird et al, 'ASIC Enforcement Patterns' (Research Report No 71, Centre for Corporate Law and Securities Regulation, University of Melbourne, 2003).

53 George Gilligan, Helen Bird and Ian Ramsay, 'Regulating Directors' Duties: How Effective Are the Civil Penalty Sanctions in the Australian Corporations Law?' (Research Report, Centre for Corporate Law and Securities Regulation, University of Melbourne, 2004).

54 David Silverman, Doing Qualitative Research (Sage, $5^{\text {th }}$ ed, 2017) 5-20. 
the investigation process was affected by legal representation - legal representation is known to affect the use of procedural rights in 'street policing'. Throughout the study, some interviewees referred to regulatory strategies associated with 'enforcement-backed compliance'. In addition, interviewees commented on their view of the 'complexity' of corporate crime - a common justification for the existence of coercive powers.

\section{Understandings of Corporate Crime}

Thirteen out of 14 interviewees acknowledged their role in prosecuting whitecollar crime. One senior manager reflected that corporate offenders 'are totally different' 55 to most criminal defendants by virtue of their wealth and power. ' $A$ company is set up to make money', said one former investigator. 'That's ultimately its original purpose ... directors of the company ... will do what they can to make money but it's up to the law to balance it out. With these ASIC powers, you're offsetting corporate power with investigative power', ${ }^{56}$ they said. 'Corporations will do what they want, they're there to make the money', ${ }^{57}$ said another. These views acknowledge an imbalance of power between the regulator and many large regulatees. As Glasbeek has asked:

Should these giant corporations, whose use of market power amounts to a coercive use of force to enable them to appropriate a larger share of the socially produced wealth, not be held responsible for the inevitable impacts on the physical, emotional and cultural welfare of countless others? ${ }^{58}$

A similar proposition was put to interviewees, most of whom actively agreed with this justification for prosecuting corporate criminality - although a handful of respondents were clear to distance themselves from the notion of that corporate power is inherently coercive. ${ }^{59}$

\section{Fairness to Suspects}

Understandings of the fairness of compulsory investigation powers echoed participants conceptions of corporate crime. For corporate lawyers among the respondents, these powers seemed 'like a fundamental breach of the rule of law' ${ }^{60}$ These sentiments resonate with a libertarian literature, universally critical of coercive law. ${ }^{61}$ The power of this literature to achieve reform, particularly in the service of large corporate interests, should not be underestimated. In Canada, for instance, the Supreme Court used similar libertarian principles, in combination

55 Interview with Anonymous 6 (Eugene Schofield-Georgeson, Sydney, 1 February 2019).

56 Interview with Anonymous 10 (Eugene Schofield-Georgeson, Sydney, 12 February 2019).

57 Interview with Anonymous 13 (Eugene Schofield-Georgeson, Sydney, 20 February 2019).

58 Glasbeek (n 4) 61.

59 Eight interviewees supported the statement while two clearly opposed it. Four neither agreed nor disagreed.

60 Interview with Anonymous 3 (Eugene Schofield-Georgeson, Sydney, 28 November 2018); Interview with Anonymous 12 (Eugene Schofield-Georgeson, Sydney, 15 February 2019).

61 Longo (n 44). 
with a new constitutional Bill of Rights, to limit the coercive power of the corporate regulator. ${ }^{62}$

A corollary perspective to this libertarian angle was an 'authoritarian' view, expressed by a former investigator who had also been a former police officer. Speaking of an interview in one of ASIC's largest corporate prosecutions, they said

basically the lawyers ... would say, 'well hold on a sec, this is a bit procedurally unfair'. To be honest, of course it's fair. Because at the end of the day you're compelling someone to make an admission about what they've done, you know. ${ }^{63}$

The problem with this perspective and the libertarian view is that they treat legal subjects as the same in all circumstances. As jurists such as Roberto Unger have observed, both libertarian and authoritarian understandings of law mask the significance of the social context in which offending occurs, ${ }^{64}$ thereby failing to grasp the necessity of procedurally coercive laws when investigating powerful corporate suspects.

By contrast, some interviewees made a connection between the strength of the powers as being assimilated to the social context at which they were targeted. As one of these respondents put it, 'I think it has just been recognised that the difference with white-collar crime is if you allow that blank wall of silence then where are you going to get? Where are you gonna get?' The respondent gave the example of fraud committed by a large bank, subject to the inquisitorial process of the Banking Royal Commission, to show the necessity of compulsory investigation powers in uncovering such crimes. ${ }^{65}$ Another said, "company directors need that compulsory power in order to be honest ... that stick at the back end needs to maybe be a little bit sharper. But overall, the powers are proportional' to the corporate crime that they were intended to investigate.66 The most senior investigator among the interviewees said,

where you're taking action against a high profile white-collar person, probably 95 percent of them are going to fight it. Whereas if you line that up alongside a typical garden variety police fraud type matter, it's probably the other way round: 90 percent of people are going to plead. So yeah basically that's another layer and reason why you need to have these coercive powers. And it is not only to get as best you can the evidence but also to be able to at least have some opportunity to rebut whatever might be asserted by a very clever and highly paid defence counsel. ${ }^{67}$

Here, interviewees bluntly considered the fairness of compulsory powers by comparing them with the social or class power of their suspects. Nevertheless, one of these interviewees added, 'we tried to be fair to these people and made sure that they understood the consequences of giving the answers that they were giving'. ${ }^{68}$

62 Thomson Newspapers Ltd v Canada [1990] 1 SCR 425; $R v S(R J)$ [1995] 1 SCR 451, 563-6, [196][205] (Iacobucci J) and the 'proportionality test', outlined in the Canada Act 1982 (UK) c 11, sch B pt I.

63 Interview with Anonymous 7 (Eugene Schofield-Georgeson, Sydney, 8 February 2019).

64 Roberto Unger, Law in Modern Society (Free Press, 1976) 176-81, 192-223.

65 Interview with Anonymous 2 (Eugene Schofield-Georgeson, Sydney, 28 November 2018).

66 Interview with Anonymous 10 (n 56).

67 Interview with Anonymous 6 (n 55).

68 Interview with Anonymous 14 (Eugene Schofield-Georgeson, Adelaide, 25 February 2019). 
Yet another cohort of interviewees admitted feeling uncomfortable about using compulsory powers, due to their perceived authoritarian associations. As a result, a good proportion of respondents conceded that compulsory powers are rarely used to their full extent. A senior manager who had worked at ASIC for over 20 years said, for instance, that they 'never went into an interview thinking, "we'll examine this guy and if he doesn't answer questions, we'll prosecute him"'. Such an approach, they explained, was counter-productive to the extraction of information. ${ }^{69}$ Instead, they said, 'ASIC didn't push the envelope in how it used those powers. It took a very consistent, conservative approach'. A further factor influencing this approach was the cautious 'model litigant' approach of the Director of Public Prosecutions ('DPP'). As the investigator put it, rather more colourfully, 'they were scared shitless of [compulsory] examination transcripts' ${ }^{70}$ When it came to 'grey lines' about 'rules around fairness', said another, 'it's better to make evidence inadmissible rather than admissible'. ${ }^{71}$ Such is the restraint with which ASIC appears to use its compulsory powers that one of the corporate lawyers who described the powers as 'odd' and 'disproportionate' nevertheless commented that 'ASIC ... are pretty good ... they're pretty reasonable with [the powers] if it's clear that the person is claiming privilege'. ${ }^{72}$ In other words, despite the apparent strength of ASIC's powers, investigators clearly do not abuse them by overuse or even manipulative use against suspects.

\section{Compulsory Investigation Process}

Interviewees, particularly those who had been ASIC investigators, gave an important array of insights into the use of compulsory powers. Beginning with the steps associated with the use of compulsory powers in the investigation process, a former senior investigator explained that,

if it blows up the front page of paper ... then ASIC does its surveillance ... goes through and gets all their books and records there, gets a witness in for an examination .... goes through the investigation process ... and if the evidence doesn't really stack up ... chooses a course of action by seeking a remedy [either through a compliance process or prosecution].$^{73}$

Another explained that surveillance commenced when ASIC received 'tip-offs from local police, or from APRA, other regulators, ACCC' and mostly, 'complaints'; 'That's when they [start to] use some of these [special] powers' ${ }^{74}$ Compulsory powers to request documents are then used to initiate the surveillance, and 'then you put together what you think your findings are on those documents'. ${ }^{75}$ As a third investigator commented, 'documents are brilliant because documents tell the story. ${ }^{76}$ This ability to know 'the story' before the interview, places investigators one step ahead of suspects.

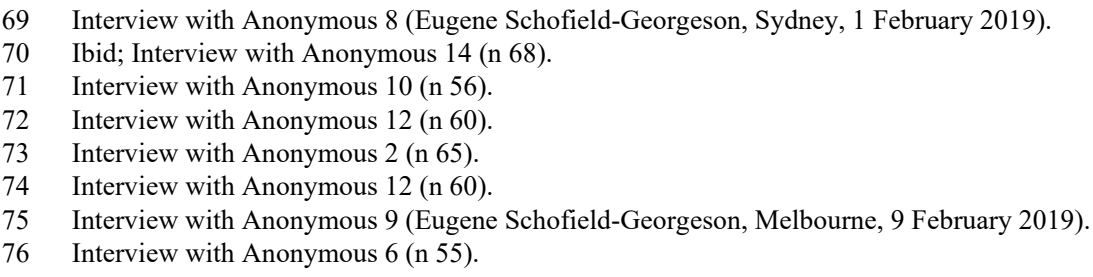


Investigators distinguished between three types of ASIC interview, saying that interviews did not necessarily commence in a compulsory way. But if a suspect or witness would not speak,

you wouldn't have been able to put it in as blunt terms as, 'if you don't answer, we're going to take action' ... but you would draw their attention to the section of the legislation and say, 'look you know this section allows us to prosecute you'. ${ }^{77}$

Such a process is clearly very different to conventional policing process in which an interviewee is protected by silence rights. Nevertheless, as the interviewees explain (above), these processes are well-assimilated to prosecuting corporate crime as mala in se crime, owing to the wealth and power of corporate suspects that otherwise enables them to evade the law.

Another investigator found that, 'the compulsory process really got them in the room but you still have to get the words out of their mouth' ${ }^{78}$ It was at this point that compulsorily seized documents became important, allowing investigators to show them to witnesses. 'It'll be a witness's oral evidence of what they say about those documents', said a former investigator, that forms the basis of the prosecution case. ${ }^{79}$ Another was more blunt. 'The beauty of it is, he has to tell us what happened ... now sometimes they'll be like, "I can't remember it was a long time ago". You'd bring up documents and they have to basically tell you', ${ }^{80}$ they said. These comments demonstrate a vital synergy between compulsory powers to obtain documents and those of compulsory interview.

Perhaps the most interesting observation about the use of compulsory powers was that they were rarely used to compel a suspect to confess in the interview room. As most investigators explained, 'we were able to establish ... all the material information relating to his wrongdoing, before [a suspect] came in' ${ }^{81}$ Another said, 'by the time you actually interview the offender, mate you should all always have enough info ... it's very rare that you actually you go to the offender first and get that info ... cops would do the exact same thing' ${ }^{82} \mathrm{~A}$ third investigator discussed the strategy behind this process, explaining that when ASIC

are after X ... they'll section 19 the PA, a business partner and maybe a client or two, some people around the edges, to get the info on X. And so X will be thinking, 'well it's going to be me next', you know, but it doesn't come, it never comes ... that's because they know that whatever X says, can't be used against him. So there's no point right, they won't bother with that. They want to get all the people around the edges because their privilege only protects them. It doesn't protect X. They can use all that stuff against $\mathrm{X}^{.3}$

In this practical respect, ASIC's powers resemble conventional investigation techniques, perhaps more than their label, 'extraordinary', might suggest.

However, as this interviewee explained, there were occasions when ASIC did in fact compel a confession from a suspect. When this happened, he explained,

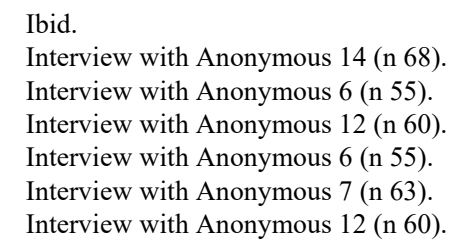


'they'd have to go around the back and find a different way in. "Secondary use" they used to talk about'. ${ }^{84}$ A senior investigator conceded that, "no-one ever goes in and thinks "I'm gonna use this [interview] transcript to secure a conviction" [but] it may well be the fruit that the transcript bares that secures that conviction $\ldots$ its derivative use' ${ }^{85}$ Nevertheless, the most senior of the investigators did describe using compulsory powers to wring a confession from a suspect in one of Australia's largest corporate crime prosecutions:

The best way of doing it is to compel them to come in ... after an hour of parading our evidence, the person adjourned with their lawyer and said, "we'd like to assist you'. Now if I was a policeman with no powers of compulsion, do you think I'd have any chance of getting to that position? ... no, because [police would] say 'come in we want to speak to you. It's only voluntary and we'll show you what we've got' ... the lawyer would just advise their client, 'don't speak to them - you're not going to the police station'. ${ }^{86}$

Compared to regular policing practices, these techniques can only be described as coercive, albeit necessary and well-assimilated to the investigation context of white-collar crime.

Investigators also described testing the limits of compulsory powers. As one investigator put it, 'how far you can go using compulsory powers, to make people actually sign a witness statement endorsing their transcript as being true and correct and getting it into court that way' ${ }^{87}$ Again, the expertise of the most senior and experienced investigator was telling here. In convincing witnesses to sign and 'stick to' their compulsory evidence, they described a process of requesting that the witness 'write or reword their statement in any way they want ... providing the witness sticks to the structure and framework and the relevance of what's in the statement' ${ }^{88}$ The investigator inferred that this process gave the witness a sense of ownership over the statement, rendering it less likely to be challenged by the defence as 'unreliable' due to coercion. ${ }^{89}$ If witnesses deviated from this evidence in court, the evidence could be used to impugn the witness's credibility. Indeed, as this investigator put it, 'that's the whole point' of the process..$^{90}$

Other senior investigators described the foremost utility of compulsory interviews as providing investigators with 'a feeling for what the defence could be' ${ }^{91}$ In turn, they described 'feeling out the defence as to where's this guy gonna come from and exploring that with the defendant, building your case around it. That was what I saw as the biggest bang for buck. What are they gonna say' ${ }^{92}$

These insights are some of the first published observations by investigators about the use of coercive powers in this context. They demonstrate the utility of

84 Ibid.

85 Interview with Anonymous 8 (n 69).

86 Interview with Anonymous 6 (n 55).

87 Interview with Anonymous 14 (n 68).

88 Interview with Anonymous 6 (n 55).

89 Such a challenge was successful in Pro Image $v$ Australian Securities and Investments Commission (Victorian Magistrates' Court, 6 December 1995) and is similar to the High Court's findings in $X 7$ (2013) 248 CLR 92.

90 Interview with Anonymous 6 (n 55).

91 Interview with Anonymous 8 (n 69).

92 Ibid. 
compulsory powers in a corporate crime context and, as the next section explains, are greatly valued by their practitioners.

\section{The Strength and Efficacy of ASIC Investigation Powers}

Most interviewees acknowledged the strength of ASIC's investigation powers, agreeing that such powers were 'extraordinary', endowing ASIC with 'a wealth of powers to gather a wealth of information'.$^{93}$ As one interviewee put it,

the reality is, it is a power that the police don't have. The police cannot compel someone to answer their questions. ASIC can. That is a fundamental difference. And yes, that important protection around self-incrimination is retained through privilege. ${ }^{94}$

Another said:

It is an intrusive power. They don't need a warrant to issue a section 19 notice ... and if used properly, it is a very powerful [and] extremely valuable investigative tool. It gets a hell of a lot of information in a very cheap, simple, effective and efficient manner. It focuses people's minds on answering the questions. ${ }^{95}$

In this respect, most interviewees saw the powers as 'absolutely effective', 'always useful', 'a blessing', 'a very valuable tool and without compulsion, prosecutions would just fall over'. ${ }^{96}$

Those who did not agree that the powers were 'extraordinary', explained that 'they're just spot on', to investigate 'white-collar, educated, professional' defendants - 'not an overreach, that's for sure'. ${ }^{97}$ On this point, a couple of interviewees referenced similar powers of 'other regulators overseas and nationally' to suggest that they were not 'extraordinary'.$^{98}$ One former investigator clearly appreciated the need to extend or assimilate interview powers in a specifically corporate context. After appraising them as 'reasonable' in respect to white-collar crime they said, 'I'd never be a fan of the police getting these types of powers for ordinary criminal matters' ${ }^{99}$

One outlying perspective was that the powers were 'odd', 'disproportionate' and had 'gone too far'. ${ }^{100}$ Another implied that the strength of these powers were in fact the cause of differentiation, laziness and complacency on the part of the regulator. 'It's great for ASIC', they said. 'It means it's easy. When you start as a grad at ASIC they say "oh it's fantastic, we can interview anyone and get what we

93 Interview with Anonymous 1 (Eugene Schofield-Georgeson, Sydney, 16 November 2018); Interview with Anonymous 4 (Eugene Schofield-Georgeson, Sydney, 28 December 2018); Interview with Anonymous 9 (n 75); Interview with Anonymous 5 (Eugene Schofield-Georgeson, Brisbane, 17 January 2019).

94 Interview with Anonymous 8 (n 69).

95 Interview with Anonymous 11 (Eugene Schofield-Georgeson, Sydney, 12 February 2019).

96 Interview with Anonymous 2 (n 65); Interview with Anonymous 5 (n 93); Interview with Anonymous 6 (n 55); Interview with Anonymous 13 (n 57).

97 Interview with Anonymous 1 (n 93); Interview with Anonymous 2 (n 65); Interview with Anonymous 5 (n 93).

98 Interview with Anonymous 2 (n 65); Interview with Anonymous 11 (n 95).

99 Interview with Anonymous 10 (n 56).

100 Interview with Anonymous 12 (n 60); Interview with Anonymous 3 (n 60). 
need"'. ${ }^{101}$ Both of these outlying views came from lawyers that now held positions as corporate defence counsel.

Overwhelmingly, interviewees expressed the view that, "ASIC has got the powers to do what it wants' - that its powers are sufficient. ${ }^{102}$ In this respect, ASIC's powers are well-assimilated to investigating and prosecuting corporate crime, suggesting that the wealth and power intrinsic to corporate crime should be met with an equally powerful response by the State. Nevertheless, as the next section demonstrates, such powers tend to be opposed by libertarians and members of the legal profession.

\section{Legal Representation and the Interview Process}

During the compulsory interview process, examinees are afforded the right to counsel. ${ }^{103}$ Nevertheless, the role of the lawyer during the examination process is restricted: lawyers must not examine their client about any matters other than those raised by the ASIC investigator ${ }^{104}$ and investigators retain power to overrule the examinee's choice of lawyer. ${ }^{105}$ When asked to estimate how frequently witnesses and suspects were legally represented in compulsory examinations, on average, respondents estimated that around $75 \%$ had legal representation. Most interviewees added that access to legal representation was almost always associated with the size of the firm at which the suspect was employed. One interviewee noted that some large Australian banks even had internal policies of paying ' 5,000 dollars' to each employee to arrange for private legal representation in ASIC interviews. 'Directors', they said, 'didn't bother with lawyers because their [personal] interests were so aligned with the business' that it was assumed their sophisticated and self-interested answers would always support the interests of the business. ${ }^{106}$ Respondents were also asked to estimate how often witnesses and suspects asserted the privilege against self-incrimination in interviews. On average, they said that the privilege was exercised regularly in $84 \%$ of cases mostly when witnesses and suspects were legally represented. None had ever encountered a case where ASIC sought to restrict an examinee's choice of legal representation.

As to the effect of legal representation on the interview process, responses were mixed. Some respondents found that it 'made it difficult for us', 'slowed us down', 'unnecessarily prolonged the process' and that 'top tier firms challenged us on every [interview] notice'. ${ }^{107}$ As one interviewee said 'some [lawyers] will put on a bit of a show for their client, showing the client that their money's wellspent and they'll treat it almost like a courtroom scenario where they'll be

101 Interview with Anonymous 12 (n 60).

102 Interview with Anonymous 11 (n 95); Interview with Anonymous 5 (n 93); Interview with Anonymous 8 (n 69); Interview with Anonymous 9 (n 75).

103 ASIC Act 2001 (Cth) s 23. Examinees are advised of this right in the section 19 oral examination notice: Australian Securities and Investments Commission Regulations 2001 (Cth) sch 2 form 1.

104 ASIC Act 2001 (Cth) s 23.

105 Australian Securities Commission v Bell (1991) 32 FCR 517, 521 (Lockhart J), 529-530 (Sheppard J).

106 Interview with Anonymous 12 (n 60).

107 Interview with Anonymous 1 (n 93); Interview with Anonymous 9 (n 75); Interview with Anonymous 8 (n 69). 
objecting to questions' ${ }^{108}$ Another expressed annoyance at what they saw as a connection between 'evasive' suspects and higher tier legal representation. ${ }^{109}$ These suspicions were confirmed by a corporate defence lawyer among the respondents who admitted that,

we actively encouraged them to say as little as possible. Good memories weren't encouraged either ... forgetfulness was a big thing ... I said 'if you're going to take time to relax, you're better off relaxing in court ... you're walking into a pit of vipers here and everything you say is being documented and recorded and used against you in every single way possible'. ${ }^{110}$

Some respondents who now worked as corporate defence counsel admitted that their goal was 'to engage a settlement more than anything else'. ${ }^{111}$ Although as one former investigator admitted, defence lawyers 'would sometimes raise issues with the way that evidence had been obtained under compulsory process ... and that might influence the DPP to not proceed with the prosecution'. ${ }^{112}$

The strength of the powers, on the other hand meant that a suspect's failure to assert privilege under compulsory examinations frequently resulted in conviction. A senior investigator recalled how when a suspect attempted to show they 'had nothing to hide' by failing to claim privilege, 'it was to their detriment. And ... the transcript became pivotal in their prosecution'. ${ }^{113}$ Similarly, inconsistent use of privilege alerted investigators to criminal behaviour and in fact assisted them to frame the charge. ${ }^{114}$ As the same senior investigator recalled, aside from 'reminding their client to say privilege before answering a question, there's not really much lawyers [can] do in examinations'. ${ }^{115}$ This situation may be contrasted with scholarship from the United Kingdom, showing that the biggest factor associated with use of the right to silence to defeat a criminal charge was the receipt of legal advice at a police station, which mostly encouraged suspects to remain silent. ${ }^{116}$ While the obfuscatory techniques discussed by corporate lawyers might be seen as a similar tactic, according to these investigators, ASIC's coercive powers are fit for the task of 'seeing through' such contrivance.

\section{Understanding Enforcement-Backed Compliance}

A handful of investigators expressed a keen understanding of the theoretical design of the regulatory framework underpinning the ASIC and Corporations Acts, in which compulsory examinations play an important role. This approach, known as 'enforced self-regulation' or 'enforcement-backed compliance' involves

108 Interview with Anonymous 8 (n 69).

109 Interview with Anonymous 4 (n 93).

110 Interview with Anonymous 3 (n 60).

111 Interview with Anonymous 4 (n 93).

112 Interview with Anonymous 14 (n 68)

113 Interview with Anonymous 6 (n 55).

114 Ibid.

115 Ibid

116 Coretta Phillips and David Brown, Entry into the Criminal Justice System: A Survey of Police Arrests and Their Outcomes (Report No 185, 1998) 72; Andrew Sanders et al, Advice and Assistance at Police Stations and the 24-Hour Duty Solicitor Scheme (Report, 1989); Stephen Moston, Geoffrey M Stephenson and Thomas M Williamson, 'The Incidence, Antecedents and Consequences of the Use of the Right to Silence' (1993) 3(1) Criminal Behaviour and Mental Health 30, 31. 
monitoring corporate compliance, backed by the threat of an increasing hierarchy or 'pyramid' of civil and criminal sanctions. It uses persuasion to enforce compliance where possible, followed by 'incapacitation where deterrence fails'. ${ }^{117}$ While not radically assimilated to the mala in se corporate crime control model discussed above, this regulatory approach is nevertheless, exceedingly more egalitarian than certain regulatory models, such as the 'consensus' or complianceonly approach deployed in jurisdictions such as the UK. ${ }^{118}$ As one investigator said, cases are dealt with at different levels of 'a pyramid', depending on their seriousness and the strength of the evidence. ${ }^{119}$ Recalling the well-known "carrot and stick' metaphor used by Ayres and Braithwaite to describe the programme of 'enforcement-backed compliance', another investigator spoke of the compulsory investigation powers as forming part of the 'stick at the back end' of the process. ${ }^{120}$ Explaining the process along similar lines to Braithwaite and Fisse, ${ }^{121}$ another said that where the regulator is 'not adequately resourced to take on the big four banks' by subjecting their executives to compulsory examination, "we just select the cases that we need to' and make an example out of them. ${ }^{122}$

\section{Complexity of ASIC Investigations}

One of the most frequent observations confirming that ASIC's compulsory powers are well-adapted to the investigation of corporate crime was that the powers enabled law enforcement officials to enquire into the peculiarly complex nature of white-collar crime and 'large complex organisations'. ${ }^{123}$ Interviewees commented that such complexity renders 'white-collar or financial crime ... a very incredibly difficult thing to prosecute', ${ }^{124}$ and 'seriously hard to prove'. ${ }^{125}$ As some of the earliest law reform commentary on the need for compulsory corporate investigation powers recognised, complexity in corporate crime stems from a range of factors including the volume of evidence, the indeterminate and specialised nature of the facts, limited liability of companies, and multiple victims in white-collar cases. ${ }^{126}$ These factors were an indelible part of the investigation experience of most interviewees.

As to the volume of evidence in corporate investigations, 'we're talking about literally hundreds of thousands of documents', said one investigator. 'There might

117 John Braithwaite, Regulation, Crime, Freedom (Ashgate, 2000) 114; John Braithwaite, 'Enforced SelfRegulation: A New Strategy for Corporate Crime Control' (1982) 80(7) Michigan Law Review 1466; John Braithwaite and Brent Fisse 'Self-Regulation and Control of Corporate Crime' in Clifford Shearing and Phillip Stenning (eds), Private Policing (Sage, 1987) 221.

118 Theo Nichols, 'Industrial Safety in Britain and the 1974 Health and Safety at Work Act: The Case of Manufacturing' (1990) 18(3) International Journal of the Sociology of Law 317; Theo Nichols and Peter Armstrong, Safety or Profit: Industrial Accidents and the Conventional Wisdom (Falling Wall Press, 1973).

119 Interview with Anonymous 2 (n 65).

120 Ibid; Interview with Anonymous 10 (n 56).

121 Braithewaite and Fisse (n 117).

122 Interview with Anonymous 13 (n 57); ibid.

123 Interview with Anonymous 6 (n 55); Interview with Anonymous 8 (n 69).

124 Interview with Anonymous 2 (n 65).

125 Interview with Anonymous 6 (n 55).

126 Use Immunity Report (n 6) [4.1]-[4.8]. 
be 50 pieces to the puzzle but you might only have 30 of them', he explained. Demonstrating the indeterminacy of this puzzle, this investigator said, "when you put those thirty in front of a jury, you're effectively asking a jury, "what do you think is in those missing pieces?" and if you've got the right pieces there already, they're going to know what they see'.127 As Sutherland has explained, differentiation of white-collar crime results in part from its complexity which, in turn, stems from the ability of corporate offenders to hire lawyers and lobby governments to manipulate and obfuscate law in their own interests. ${ }^{128}$

Limited liability or the corporate veil is Sutherland's classic example of manipulation of law to protect white-collar criminality. ${ }^{129}$ Interviewees referred to the 'corporate veil' as another obfuscatory factor in corporate criminal investigation that justifies coercive powers.

You're offsetting against the kind of inherent complexity of what you're investigating and the otherwise kind of privileged position that the person has actually been given [through] things like the corporate veil [which] immediately puts up a wall that prevents prosecution ... or makes it extremely difficult to prosecute individuals

said one former investigator. ${ }^{130}$ Other interviewees described this quid pro quo relationship or social contract as a form of 'social licensing'. '131 'If you don't want the ... license ... just don't run a business', said another. ${ }^{132}$ Conceiving of this process as one of licensing contains an inherent acknowledgement that there is something harmful about corporate profit-making, necessitating regulation. Glasbeek identifies this harm as involving 'the private accumulation of socially produced wealth', in a manner that is not only lawful, but protected by complex law. ${ }^{133}$

A related issue of complexity was best explained by a senior investigatorturned corporate barrister, who said,

making, building a white-collar case is really, really difficult. You know, a murder case ... he didn't put the knife in his own back. Somebody put it there and that is inherently an unlawful thing. These white-collar things, market manipulation, insider trading stuff, for example. The basic issue is has an offence been committed?' The criminal law analogy is rape - where sexual acts are not illegal, but if you have a particular intent and you carry out the sexual act in a particular way, then it can be highly illegal. Trading on the share market is not illegal. We want people to go and have sexual relations or else the human race is done and we want people to trade on the share market but if you trade in a certain way and with a certain intent, that is then all of a sudden a serious illegal act. Rape is the hardest crime to prove. It's the same with these intent-based white-collar crimes. ${ }^{134}$

He added that the elaborate nature of corporate defences - some of which might turn on the interpretation of a word in company prospectus - all added to

127 Interview with Anonymous 6 (n 55).

128 Sutherland, 'White-Collar Criminality' (n 13) 8.

129 Ibid.

130 Interview with Anonymous 10 (n 56).

131 Interview with Anonymous 9 ( $\mathrm{n} 75$ ).

132 Interview with Anonymous 10 (n 56).

133 Glasbeek (n 4) 4

134 Interview with Anonymous 11 (n 95). 
the complex indeterminacy of corporate crime. ${ }^{135}$ These complexities directly resonate with Sutherland's definition of white-collar crime in which acts that are technically lawful, could and should be criminalised due to their inherent dishonesty and often exploitative consequences..$^{136}$

Coming from the opposite political direction, one corporate defence lawyer among the interviewees insinuated that such indeterminacy meant that corporate crime was arbitrary and hence, illegitimate. As they put it,

One of the great tensions in corporate law trials is you have to balance the court second guessing management decisions in which these people are usually experts. 'You bought this type of wood and not that type of wood and it bankrupted the company. How dare you!' We don't know enough about wood so, a criminal trial. You know, 'beyond all reasonable doubt, should they have bought the other wood?', seems like an absolute nonsense. ... I can't see many instances where [a legitimate conviction] could be done .... So unless you had outrageously self-interested behaviour, that's simply not going to happen. Most of these corporate cases are mild negligence, inattentiveness, minor moments of greed. The problem is that minor moments of greed in charge of huge monstrous organisations have huge consequences for those little actions. ${ }^{137}$

The final aspect of complexity raised by interviewees concerned the element of multiple victims often affected by corporate offending - an aspect commonly associated with increasing the 'gravity' or mala fides of conventional criminal offending. The number of 'witness statements' generated by the 'widespread impact' involved with corporate offending, said one interviewee, 'justifies ASIC having those powers'. ${ }^{138}$ Citing examples of banking conduct from the Banking Royal Commission, one interviewee said that these corporate suspects commit crime that ranges 'across all of Australia and it's just the breadth of their impact' that means the powers are 'proportionate to the work that ASIC is trying to do'. ${ }^{139}$ In response to the combined complexities surrounding issues of volume of evidence, indeterminacy and limited liability, senior investigative officials were emphatic that the work of ASIC 'would be hampered, without those powers'. ${ }^{140}$

\section{B Differentiation and Under-Enforcement of Corporate Crime Related to ASIC's Special Powers}

\section{Differentiation of Investigation Powers}

Just as interviewees discussed assimilation of investigative powers to corporate crime, so too did they explain how these powers are differentiated from

136 Sutherland, White Collar Crime: The Uncut Version (n 16) 45-62, 135-52, 153-73; Glasbeek (n 4) 6. Relatedly, the Banking Royal Commission recently confirmed that the standard of dishonesty to be applied to corporate offending is not a highly technical standard based on 'reasonable company directors', but rather, that which applies to dishonesty offences under general criminal law such as street crime or larceny. Such a standard, requires an objection perception of dishonesty as it is understood by 'ordinary, honest' or 'ordinary decent people': see, eg, Peters v The Queen (1998) 192 CLR 493, 503 [15] (Toohey and Gaudron JJ); R v Feely [1973] QB 530, 535-41 (Lawton LJ for the Court); Banking Royal Commission (n 2) vol 1 156-7.

137 Interview with Anonymous 3 (n 60).

138 Interview with Anonymous 9 (n 75).

139 Ibid.

140 Interview with Anonymous 8 (n 69); Interview with Anonymous 6 (n 55). 
the enforcement of regular criminal law, outlined in here in Part B of this article. Most agreed that while ASIC has very strong powers assimilated to the enforcement of corporate crime, the powers are rarely used, meaning that corporate criminal law remains under-enforced. Under-enforcement was a key point recognised recently by the Banking Royal Commission. 'ASIC's starting point', said Commissioner Hayne, 'appears to have been: "How can this be resolved by agreement?"', rather than asking "whether a Court should determine the consequences of a contravention' - whereas the 'starting point' required by 'the rule of law' is that 'the law is to be obeyed and enforced', while 'adequate deterrence of misconduct depends upon visible public denunciation and punishment' ${ }^{141}$ Counsel assisting the Banking Royal Commission pointed out this differential treatment between corporate crime and 'street crime' in a question to the current ASIC Chairman, saying, 'The parking inspector doesn't seek an indication from the person he's giving a parking fine to as to whether they will accept and pay it. He just does it. Why don't you just do that?' ${ }^{142}$

This suggestion translated into a key observation in the Banking Royal Commission final report that, "the critical question whenever ASIC is considering any contravention of the law must be ... "Why not litigate?" ${ }^{143}$ ASIC's official answer to this question had previously been associated with compliance-based prosecution practice, supported by a large regulatory literature emphasising 'improved regulatory outcomes' through 'mutual trust' between regulators and regulatees, backed by gentle regulatory 'suasion' involving negotiation of agreements, promises and 'enforceable undertakings'. ${ }^{144}$ Given the extent of corporate criminality uncovered by the Banking Royal Commission, however, it was clear that these strategies had failed, weakening, rather than strengthening, the relationship between regulator and regulatee. These results reinforced Commissioner Hayne's recommendations that compliance strategy should not be contemplated without first considering prosecution and its attendant deterrent outcomes - both specific and general. ${ }^{145}$

Despite recognising ASIC's differential treatment of corporate crime and prosecution strategy, the Banking Royal Commission did not engage with its institutional causes. In this study, interviewees identified a range of reasons for differentiated patterns of enforcement. Most associated a neoliberal political agenda and polices of deregulation and austerity with failure to use coercive investigative powers. Interviewees consistently mentioned how funding and staffing polices, as well as formal enforcement policy (ironically, directed against

141 Banking Royal Commission (n 2) 424-33 Recommendation 6.2.

142 'Banking Royal Commission: ASIC's Awakening Is Just Weeks Old', The Australian Financial Review (online, 23 November 2018) <https:/www.afr.com/chanticleer/banking-royal-commission-asicsawakening-is-just-weeks-old-20181123-h188yt $>$.

143 Banking Royal Commission (n 2) 426-7 Recommendation 6.2.

144 Royal Commission into Misconduct in the Banking, Superannuation and Financial Services Industry (Interim Report, 28 September 2018) 271-6. See, eg, the work of the 'Oxford compliance school' of regulation theorists such as Robert Baldwin, Rules and Government (Clarendon Press, 1995); Bridget M Hutter, Compliance, Regulation and Environment (Oxford University Press, 1997); Keith Hawkins, Law as Last Resort: Prosecution Decision-Making in a Regulatory Agency (Oxford University Press, 2002).

145 Banking Royal Commission (n 2) 425-6. 
enforcement) led to the regulatory 'capture' of ASIC by wealthy and powerful business interests and, in turn, minimal use of its coercive investigation powers.

Empirical studies on ASIC enforcement between 2011 and 2016 do not indicate any substantive decline in prosecutions, and hence the use of ASIC's investigative powers. ${ }^{146}$ Nevertheless, when small business prosecutions are subtracted from these enforcement outcomes, only $30 \%$ of ASIC investigations result in criminal sanctions, with the remainder comprising banning and licensing actions and enforceable undertakings. ${ }^{147}$ As interviewees made clear, ASIC rarely uses its extraordinary powers in such matters because it is rarely required to produce strong evidence to secure these 'compliance' measures. ${ }^{148}$ As one interviewee put it, compliance measures are negotiated 'because ASIC wants to try and get a nice quick easy result'. ${ }^{149}$ As the foregoing explains, these differentiated outcomes are the result of neoliberal austerity measures and deregulation.

\section{Resourcing}

Differentiated use of investigation powers through under-enforcement is typically the result of inadequate funding resulting from neoliberal austerity measures. ${ }^{150}$ Over the past decade, both Labor and Liberal Party governments have cut funding to ASIC. ${ }^{151}$ Former Prime Minister Tony Abbott introduced the most severe cuts in 2014, stripping \$120 million from the ASIC bottom-line. ${ }^{152}$ Since the Banking Royal Commission, this money has been restored, with additional resources allocated to the regulator. ${ }^{153}$ As interviewees explained, limited resources restricted the use of coercive powers, in some cases rendering the organisation subject to 'capture' by large, powerful and wealthy corporate interests. ${ }^{154}$

At the time of the Abbott Government cuts, one investigator recalled that, 'ASIC was always brutally made aware of the fact that you're using public funds' which even affected 'very minute, low level decisions about stationery'. They explained that on such a budget, when 'you start investigating and opening doors

146 Ramsay and Webster (n 51) 299; Ruth Williams, “"They Haven't Got the Balls”: Spotlight Falls on Company Cop', The Sydney Morning Herald (online, 27 April 2018)

$<$ https://www.smh.com.au/business/banking-and-finance/they-haven-t-got-the-balls-spotlight-falls-oncompany-cop-20180427-p4zc3m.html>.

147 Ramsay and Webster (n 51) 297-300.

148 Interview with Anonymous 3 (n 60); Interview with Anonymous 7 (n 63); Interview with Anonymous 9 (n 75); Interview with Anonymous 11 (n 95).

149 Interview with Anonymous 7 (n 63).

150 Tombs and Whyte (n 4) 147-51.

151 Alistair Waters, Submission No 125 to Senate Standing Committee on Economics, Inquiry into the Performance of the Australian Securities and Investments Commission (ASIC) (21 October 2013) 1.

152 'Georgia Wilkins and Nassim Khadem, 'ASIC Lashes Budget Cuts', The Sydney Morning Herald (online, 29 October 2014) <https://www.smh.com.au/business/asic-lashes-budget-cuts-20141029$11 \mathrm{dr} 2 \mathrm{c} \cdot \mathrm{html}>$.

153 Josh Frydenberg MP, 'Record Funding and Resources for ASIC and APRA to Help Restore Trust in Australia's Financial Sector' (Media Release, 22 March 2019)

$<$ https://ministers.treasury.gov.au/ministers/josh-frydenberg-2018/media-releases/record-funding-andresources-asic-and-apra-help>.

154 Interview with Anonymous 11 (n 95); Interview with Anonymous 5 (n 93); Interview with Anonymous 8 (n 69). 
to do big things' and 'you think that you might get knocked back [on the prosecution] anyway', that 'ASIC's first position' becomes 'how do we settle this?' 155 As another put it, 'it's about trying to do as much as they can with the resources they've got'. ${ }^{156}$ Almost all interviewees expressed a view that valuable investigative resources are allocated to other areas of ASIC's overly broad regulatory charter of operations - a view that, "ASIC does far too much' ${ }^{157}$ while its 'remit is getting wider and wider'. ${ }^{158}$

But even with adequate funding, standard regulatory operations are limited by government resources. As another investigator put it, 'when you're a corporate regulator with limited resources and you're pitted against all the big banks with almost infinite resources, it's almost always very hard to win'. ${ }^{159}$ Junior investigators expressed reluctance to prosecute while feeling intimidated by the wealth and power of corporate investigatees. ${ }^{160}$ Against large corporate interests, ASIC 'knows what'll happen', said another, - 'it will be wrapped up in years of defence'. ${ }^{161}$ Citing ASIC's largely fruitless prosecution of OneTel Corporation around a decade ago, interviewees spoke of the 'risk', 'waste of resources' and collective demoralisation associated with losing corporate prosecutions, which in the OneTel case were compounded by a costs order against the regulator. ${ }^{162}$ In this way, limited resources have seen the regulator refrain from exercising its powers, rendering it captive to large, wealthy and powerful interests, an inequality of resources that differentiates it from conventional police forces.

\section{Staffing Policy and Skills Decline}

Neoliberalism is commonly associated with the politics of 'short-termism' short-term planning and decision-making for short-term private financial gains, often at the expense of good social governance and long-term economic prosperity. ${ }^{163}$ Neoliberal management at ASIC has followed this trajectory in respect to staffing policies which have, in turn, impacted significantly upon the exercise of ASIC's special powers. At the same time as increasing the numbers of senior executive staff with solid finance sector credentials, sympathetic to large corporate interests, ASIC has systematically 'downsized' the number of experienced investigative staff who, between them, maintained important institutional knowledge about ASIC's special investigative powers.

Senior investigators claimed that the problem of under-enforcement was not one of resourcing but 'skills, they're lacking skills', said one. 'You can give ASIC a thousand [new] staff if you want but if they don't have the skills, they're not

155 Interview with Anonymous 1 (n 92)

156 Interview with Anonymous 12 (n 60).

157 Interview with Anonymous 4 (n 93).

158 Interview with Anonymous 12 (n 60).

159 Ibid; Interview with Anonymous 4 (n 93).

160 Interview with Anonymous 12 (n 60); Interview with Anonymous 10 (n 56).

161 Interview with Anonymous 1 (n 92).

162 Interview with Anonymous 7 (n 63).

163 John David Bone, 'Irrational Capitalism: The Social Map, Neoliberalism and the Demodernization of the West' (2010) 36(5) Critical Sociology 717, 717; Ben Fine and Alfredo Saad-Filho, 'Thirteen Things You Need to Know about Neoliberalism' (2016) 43(5) Critical Sociology 685, 691. 
gonna be able to do it'. ${ }^{164}$ Others expressed similar views but were also critical of what they saw as a misallocation of funds on more management and free market policy. ${ }^{165}$ As another senior investigator said,

recently it was announced that ASIC had increased the number of managers or senior executives. For me, that's crazy. It's not about increasing penalties or increasing powers it's making sure your workforce is properly trained and the right numbers are there to do the job rather than increasing the number of managers. For me that was madness. ${ }^{166}$

Disagreeing that ASIC was 'underfunded', this investigator continued, saying, 'I look around the organisation and you've got all these teams and what do they actually accomplish?' Singling out one former ASIC Chairman, they said,

I remember that his key thing was what he called 'facilitating capital market flows'. And I used to say, 'What the hell does that actually mean? Where does it say in ASIC's charter or the Act that we're set up to do that!' I'm all for surveillance teams. ${ }^{167}$

They were moved to anger at the way in which a certain ASIC Chairman had offered 'redundancies' to experienced members of the enforcement team, for whom 'he had near contempt'. The 'redundancies', said this senior investigator, were 'aimed purely at enforcement and some damned good people went as a result of that. I remember thinking at the time, "what the hell! This is madness! How can you be gutting enforcement! ${ }^{168}$ Such sentiments are an entirely rational response to neoliberal policy in which practices of state-based market regulation are themselves informed not by traditional legal concepts such as fairness and formal equality, but by predatory and unpredictable market logic - what economist, David Harvey, has recently called 'the madness of economic reason' ${ }^{169}$

Senior investigators were replaced with executives and corporate lawyers who 'had no relevant experience in this space.' The same senior investigator spoke of 'incompetence' and a 'total lack of experience' in senior ranks, saying that 'some of the suggestions' to the investigation and enforcement teams 'were, to be quite blunt, garbage, inane, inane' ${ }^{170}$ The interviewee continued, saying that 'knowledge of markets' did not translate into knowledge of 'how to go about prosecuting in the market', resulting in 'embarrassing' decisions by the senior executive. 'If I had very junior staff ... [who] had suggested' certain decisions made by the senior executive, the interviewee said, 'I would have had a very stern word with them, saying, "that's a preposterous suggestion"'. In this respect, differentiation of corporate crime from regular crime was not inherently 'cultural' among investigators. Rather, it was engineered from the top-down. This former investigator blamed a particular ASIC Chairman whose policies 'significantly advanced the skill set drain that we're seeing', leading the organisation to

164 Interview with Anonymous 6 (n 55).

165 Interview with Anonymous 5 (n 93).

166 Interview with Anonymous 8 (n 69).

167 Ibid

168 Ibid

169 David Harvey, Marx, Capital and the Madness of Economic Reason (Profile Books, 2017).

170 Interview with Anonymous 8 (n 69). 
'plummet'. ${ }^{171}$ The most senior of the investigators emphasised a lack of skills among junior staff, hired to replace older, experienced investigators whose jobs had apparently been made redundant. ${ }^{172}$

The most noticeable consequence of this skill drain affected the use of coercive investigation powers. As the most experienced investigator said, during interviews, 'you need to make sure that the right questions are asked, in order to meet the elements of the offence. Section 19s ... were often in the hands of quite junior practitioners' and either 'the right questions weren't asked' or inexperienced investigators 'were railroaded by the defendant's lawyer'. ${ }^{173}$ This investigator had performed over 400 compulsory examinations and spoke at length about the 'safest' and most unimpeachable ways to conduct the interview. ${ }^{174}$ Similarly, in reviewing compelled documentary evidence, they said, 'a rookie investigator would' not necessarily 'understand exactly what they've got and whether there are gaps'. Most, said this senior investigator, are not 'actually carefully reviewing' compelled material 'because they don't know yet what to look for' ${ }^{175}$ They emphasised the importance of training and learning these skills over time - often over the space of a five to 20-year career. It is precisely such a career trajectory that short-term ASIC staffing policy has obliterated, along with the ability to master the use of the institution's special investigation powers.

\section{Internal Enforcement Policy}

Enforcement policy within ASIC is a further factor differentiating its use of coercive investigation powers. Such policy reflects broader neoliberal institutional goals of deregulation that appear synchronised with powerful and wealthy interests. This synchronicity emerged during the 2013 federal election campaign agenda of right-wing Liberal Party Prime Minister, Tony Abbott, who promised a deregulated, minimalist, neoliberal state, embodied by a sloganeering pledge to 'cut red tape' or, rather, business regulation. ${ }^{176}$

One interviewee admitted to being 'disgusted' by ASIC 'market releases about how they're cutting red tape'. Pointing to the emphatically politicised nature of these statements, they said, 'reasonable people can disagree about the appropriate level of regulation in a particular area of the economy but ASIC's calling it "red tape", calling regulation "red tape" is a value judgement', that is antithetical to the very existence of the regulator. ${ }^{177}$ Again, this interviewee made a connection between wealthy and powerful interests and neoliberal government policy, internalised by ASIC. 'Maybe, you're actually scrapping regulations that are well crafted to protect investors and stakeholders,' they said, 'and you're only doing it

171 Ibid.

172 Interview with Anonymous 6 (n 55).

173 Interview with Anonymous 5 (n 93).

174 Interview with Anonymous 6 (n 55).

175 Ibid.

176 This agenda was formalised on numerous government websites while a day in the Australian Parliament was nominated as 'cutting red tape day' in which 9000 business regulations were abolished. See Tony Abbott, 'A Message from the PM - Cutting Red Tape' (YouTube, 15 March 2014) $<$ https://www.youtube.com/watch?v=GbNa4t9RvaQ $>$. Interview with Anonymous 11 (n 95). 
because you've been lobbied by financial services firms'. ${ }^{178}$ Other interviewees were somewhat less critical of the links between capital and the state, opting instead for traditional liberal explanations of failures to exercise investigation powers that largely blamed or failed to look beyond, 'big government'. 'It was a big bureaucracy and we always seemed to prosecute those really, really easy cases or those cases that weren't really big firms', said one. ${ }^{179}$ 'Honestly, I think it's that they have an adverse risk approach and I think that just has developed within the culture' and now ASIC 'rarely prosecutes', said another. ${ }^{180}$ Much like the critique that emerged from the Banking Royal Commission, these perspectives did not look below the surface of institutional under-enforcement to the guiding hand of neoliberal strategy.

Nevertheless, these views yielded further detail about ASIC's enforcement policy. After writing enforcement policy at ASIC, one senior investigator explained that ASIC did not say, 'this conduct is not acceptable. We think it's illegal. Don't do it'. ASIC would instead say, 'although these arrangements may not be illegal, we have some concerns'. ${ }^{181}$ In this respect they criticised deregulation-styled policies of 'compliance' which they said gave 'ASIC a peculiar personality where it's trying to be really helpful but at the same time ... hedges its bets ... making enforcement more difficult'. ${ }^{182}$ As long-time scholars of ASIC policy such as Vicky Comino have realised, enforcement is not actually an objective of such compliance-oriented corporate regulation. ${ }^{183}$

Unsurprisingly perhaps, compliance-oriented enforcement strategy was endorsed by corporate lawyers among the interviewees. More concerning, however, were views on enforcement powers attributed to a past ASIC Chairman by one of these lawyers, with whom the lawyer claimed to have worked closely. 'His view was that ASIC was instilled with too much power', turning 'a supposedly responsive regulator ... into quite an aggressive beast', the lawyer said. ${ }^{184}$ This tendency toward deregulation was paraded publicly in the approach of another recent ASIC Chairman, Greg Medcraft, a former banker specialising in the securitisation of non-mortgage assets (or 'credit default swaps' ('CDS')) in Europe and later, North America, throughout the 1990s until 2006. ${ }^{185}$ The proliferation of CDS in the United States during the leadup to the Global Financial Crisis ('GFC') in 2007 relied upon deregulation of anti-trust laws following active lobbying by major proponents within the industry. The de-regulation of CDS has

178 Ibid.

179 Interview with Anonymous 4 (n 93).

180 Interview with Anonymous 9 (n 75).

181 Ibid.

182 Ibid.

183 Vicky Comino, 'Towards Better Corporate Regulation in Australia' (2011) 26(1) Australian Journal of Corporate Law 6, 36.

184 Interview with Anonymous 3 (n 60).

185 Lucinda Schmidt, 'Profile: Greg Medcraft: The New ASIC Chairman Attributes his Outstanding Success to a Can-Do Attitude', The Sydney Morning Herald (online, 10 August 2011); Aleks Vickovich, 'ASIC Vows to Cut Red Tape', Independent Financial Advisor (online, 12 September 2013). 
been widely cited as a cause of the GFC. ${ }^{186}$ Following the GFC, Medcraft returned to Australia. He was appointed ASIC Chairman shortly after.

Senior investigators provided examples of how deregulatory approaches resulted in failure to prosecute and use coercive powers. In a follow-up 'off the record' interview, one of the most senior investigators spoke of how ASIC investigators discovered that one of Australia's largest banks had 'stolen or misappropriated billions of dollars from term deposit accounts'. ${ }^{187}$ When it was brought to the attention of ASIC's highest ranking officials, the corporate watchdog declined to prosecute ${ }^{188}$ - even after receiving affirmative written legal advice from two separate senior counsel. As the interviewee put it, 'we were never going to lose'. Similarly, another former investigator spoke of providing a detailed tip-off to ASIC on a \$35 million dollar investment fraud case, disclosing all relevant details of offences, including transactions, accounts, emails. 'I basically wrapped this up, gave it to them and all they had to do was just issue some section 19 notices, call these people and get them to produce documents and financial statements and they'd have a prosecution', they said. ${ }^{189}$ ASIC failed to act. As another investigator explained, 'if, for example, it was going to take Catherine Brenner (former Chair of AMP) in ... for an interview, that might look embarrassing to ASIC, or there could be questions, or it could raise eyebrows, so I don't think they ever did that'. ${ }^{190}$

\section{Capture of ASIC}

Some of the most extraordinary examples of ASIC's regulatory capture were cited by a former ASIC legal officer-turned-whistleblower. The first example involved what they described as 'a full court press from lobbying groups like the Financial Services Council ... trying to get ASIC to change the law to benefit it'. These amendments, they said were 'just rammed through in circumstances where I thought ASIC just didn't have the power to do it'. When this respondent spoke out against these dealings to the most senior legal officials within ASIC, they were told that 'saying "no" just wasn't an option' and that continued resistance risked not only their job but their admission as a solicitor in NSW. ${ }^{191}$

When a superannuation fund lobbied ASIC to repeal fee disclosure obligations for online superannuation calculators, ASIC established 'a dedicated team' to deal with their submissions. The team included the lawyer from the same superannuation fund (now head of a major investment bank) who had drafted the

186 Frank Heyde and Ulrike Neyer, 'Credit Default Swaps and the Stability of the Banking Sector' (2010) 10(1) International Review of Finance 27; Shanuka Senarath and Richard Copp, 'Credit Default Swaps and the Global Financial Crisis: Reframing Credit Default Swaps as Quasi-Insurance' (2015) 8(1) Global Economy and Finance Journal 137.

187 Off-the-record interview. The story has been pursued in some detail in the press. See Ben Butler, 'D'Aloisio Shelved CBA Inquiry', The Australian (online, 8 January 2018).

188 ASIC Chairman, Tony D'Aloisio, has since commented that, 'the unacceptable industry practices on term deposits ... were publicly disclosed at the time and stopped ... This was a regulatory outcome which did not involve the risk and cost of litigation': Butler (n 187).

189 Interview with Anonymous 11 (n 95).

190 Interview with Anonymous 9 (n 75).

191 Interview with Anonymous 11 (n 95) 
correspondence lobbying ASIC to change the laws. ${ }^{192}$ ASIC senior managers dismissed the whistleblower's concerns that such an apparent conflict of interest constituted a criminal offence under the $A$ SIC Act. ${ }^{193}$ And when a major investment bank lobbied ASIC to legalise what the whistleblower referred to as, 'a largescale tax dodge', ASIC could provide only the most feeble of responses. The interviewee described how the major law firm representing the bank 'misrepresented the law' and 'the way their scheme operated'. ASIC very nearly capitulated, were it not for his insistence against legalising the scheme. Upon suggesting to ASIC senior management that the firm be admonished for its improper legal practice and disrespect toward the regulator, the whistleblower was reprimanded as being 'crazy', given the wealth, power and prestige of both the firm and their client. ${ }^{194}$ This interviewee did not see the problem in terms of corruption but merely as reflecting the 'extreme political power' of 'a very powerful, wealthy set of people who are lobbying for this stuff' in a 'very aggressive, very assertive' way, showing that they had 'infinite resources, infinite lawyers'. ${ }^{195}$ These anecdotes clearly illustrate largescale differentiation in ASIC's enforcement of corporate crime - in particular, Sutherland's observation that white-collar criminals are equipped not only to evade the law but to change it in their own interests. ${ }^{196}$

After the percolation of neoliberal management strategies discussed above, other interviewees described an entrenched culture of capture. The regulator is now 'filled with people who have worked either for the large law firms or for the large banks or they go back and forth ... and they're all pals!', said one. ${ }^{197}$ 'There is a culture of ... looking after the big end of town', said another, ${ }^{198}$ and 'if you're big enough, you usually get an RM [relationship manager]'. Relationship managers are ASIC employees who manage the compliance affairs of 'all the big stockbroking firms, banks, investment banks'. ${ }^{199}$ This mutually embedded culture of compliance between large firms and the regulator is far removed from the practical experience of investigators tasked with using coercive powers against corporate crime. Such regulatory capture is so different from the policing of street crime that it might easily be mistaken for the state-sanctioned equivalent to police corruption.

\section{- V CONCLUSION}

ASIC's special powers are, undoubtedly, fit for the purpose of investigating corporate crime and assimilated to the task of treating it as such. In the interviews undertaken here, investigators and others described, for the first time, how such

193 ASIC Act 2001 (Cth) s 125 - 'fail ... to avoid the conflict [of interest]', etc. These concerns were also dismissed by the Commonwealth Ombudsman: ibid.

194 Interview with Anonymous 11 (n 95).

195 Ibid.

196 Sutherland, 'White Collar Criminality' (n 13) 7.

197 Interview with Anonymous 5 (n 93).

198 Interview with Anonymous 4 (n 93).

199 Ibid 
powers are used and to what effect. But interviewees also explained that these procedural powers are subject to political manipulation, often by forces that operate high above the heads of individual investigators. In this respect they raised a range of significant issues concerning the operations of ASIC that differentiate coercive powers from conventional powers of street policing.

The Federal Government's response to the Banking Royal Commission findings against ASIC's problems with differentiated enforcement have been mixed. On the one hand, the Morrison Government has been forthcoming with an injection of funding, replacing what has been stripped-out of the organisation by recent neoliberal austerity measures. On the other hand, enforcement options have been further differentiated, with the creation of more lenient civil penalty and 'quasi-criminal' options for dealing with corporate crime. ${ }^{200}$ Accordingly, the advice and outcomes of the Banking Royal Commission may not result in any greater assimilation of enforcement practices by ASIC, unless the regulator prosecutes corporate crime using existing offence provisions that have more serious, criminal consequences. In turn, such offences require proof of more serious offending 201 and ASIC's special powers are well-equipped and assimilated to the task of collecting such evidence. Whether these powers are in fact used in this way, will depend on a response to the problems of differentiation, discussed above. In addressing these issues, investigators require a discrete set of skills.

As this article has argued, supported by qualitative evidence, these skills and the institutional knowledge about how to use them that had accrued within ASIC over time, have largely been lost to a short-sighted neoliberal political agenda. This is an agenda that has ascribed primacy to the goals of austerity and market freedom at the expense of the longevity and fairness of the market (discussed in Part B). No amount of 'quick-fix' prosecution policy and funding restoration can solve this problem in the short-term. Also demonstrated here is that ASIC management have actively inculcated a culture of compliance, discouraging assimilated enforcement and deterrent strategies of prosecution and coercive investigation. Broader institutional and political change is needed within the regulator for its coercive investigation powers to be properly assimilated to the task of enforcing the law against corporate crime. Precise policies geared toward this goal require further research from a critical regulation perspective. ${ }^{202}$ Nevertheless, change begins with abandoning polices of deregulation which, as demonstrated here, have assisted

200 Corporations Act 2001 (Cth) s 1317E, as inserted by Treasury Laws Amendment (Strengthening Corporate and Financial Sector Penalties) Act 2019 (Cth) sch 1 item 116; NSW Society of Labor Lawyers, 'Post-Hayne: The State of Financial Regulation in Australia' (YouTube, 28 April 2019) $<$ https://www.youtube.com/watch?v=1PvUHxj3dXo $>$.

201 See, eg, offences requiring proof of 'actual dishonesty'.

202 A key avenue of further research arising from this study is the overly cautious treatment of compulsory interview material by the DPPs and courts - both bodies appear to either misunderstand white collar crime or disapprove of the sociological justification for these powers. A further issue was confusion surrounding the use and justification of coercive powers by some ASIC investigators and senior managers. Yet another concerned restraint against use of compulsory powers out of consideration for the best interests of victims of corporate crime. Interviewees also raised a raft of suggestions to more effectively assimilate the use of ASIC's special powers of investigation. 
wealthy and powerful interests to commit corporate crime, in part, by capturing the regulator. 
Copyright of University of New South Wales Law Journal is the property of University of New South Wales Law Journal and its content may not be copied or emailed to multiple sites or posted to a listserv without the copyright holder's express written permission. However, users may print, download, or email articles for individual use. 